\title{
Effects of press- mud pre-treatment on the feasibility of biogas production
}

\author{
Efecto del pre-tratamiento de la cachaza en la factibilidad de la producción de biogás
}

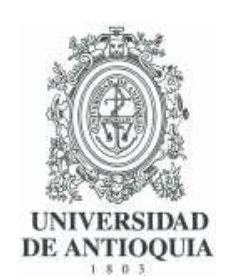

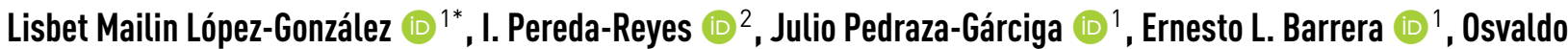 \\ Romero-Romero (iD)' \\ ${ }^{1}$ Centro de Estudios de Energía y Procesos Industriales (CEEPI). Universidad de Sancti Spíritus “José Martí Pérez" (UNISS). Avenida de los \\ Mártires 360. C.P. 60100, Sancti Spíritus, Cuba. \\ ${ }^{2}$ Centro de Estudios de Ingeniería de Procesos (CIPRO). Universidad Tecnológica de La Habana "José Antonio Echeverría" (Cujae). Calle \\ 114 \#11901 e/ Rotonda y Ciclovía. Marianao. C.P. 19390, La Habana, Cuba.
}

\section{CITE THIS ARTICLE AS:}

L. M. López, I. Pereda, J. Pedraza, E. L. Barrera, 0. Romero, "Effects of pressmud pre-treatment on the feasibility of biogas production", Revista Facultad de Ingeniería Universidad de Antioquia, no. 92, pp. 51-59, Jul-Sep 2019. [Online]. Available: https : //www.doi.org/ 10.17533/udea.redin. 20190520

\section{ARTICLE INF0:}

Received: November 20, 2018

Accepted: April 28, 2019

Available online: May 23, 2019

\section{KEYWORDS:}

Biogas, feasibility studies, environmental impact

Biogás, estudio de viabilidad, impacto ambiental

\begin{abstract}
In this study, an energetic, economic and environmental feasibility for the anaerobic digestion (AD) of press mud previously pre-treated with liquid hot water (LHW) or thermo-alkaline (TA) methods were assessed. A typical Cuban sugar mill was selected as Case Study. The sugar mill has a potential capacity to process $4,600 \mathrm{t} \mathrm{d}^{-1}$ of sugar cane and operates 130 days per year. The biogas produced can be used to feed an internal combustion engine to produce electricity and heat. It was assumed that the electricity will be sold to the national electric grid and the heat recovered from the exhaust gases will be used as energy source to supply the thermal demand for press mud pre-treatments. The thermal requirements for pre-treatments $\left(9.4\right.$ and $\left.12.1 \mathrm{MWh} \mathrm{d}^{-1}\right)$ were energy sufficient by recovering the heat from the engine exhaust. For the alternatives considered, an improvement of the environmental profile with respect to the reference scenario was obtained. The profitability of methane production also increased for alternatives considering pre-treatment. In general, the economical, energetic and environmental assessment showed the best indicators for the AD of press mud using LHW pre-treatment.
\end{abstract}

RESUMEN: En este estudio se evalúa la factibilidad energética, económica y ambiental de la digestión anaerobia de la cachaza pre-tratada por agua caliente presurizada y por pre-tratamiento termo-alcalino. Una empresa azucarera típica en Cuba, con 4,600 t/d de caña molida y 130 días de operación, se seleccionó como caso de estudio. El biogás producido será usado para alimentar un motor de combustión interna para producir electricidad y calor. Se asumió que la electricidad será vendida a la red nacional y el calor que se recupera de los gases de escape del motor será usado como fuente energética para los pre-tratamientos. Los requerimientos térmicos para los pre-tratamientos permitieron cubrir el consumo de energía requerido. También una mejora ambiental y económica se obtuvo para las alternativas con pre-tratamiento. En general los mejores indicadores ambientales, económicos y energéticos se obtuvieron para la digestión anaerobia de la cachaza pre-tratada por agua caliente presurizada.

\section{Introduction}

Sugar and alcohol factories generate highly polluting wastes such as vinasse and press mud. Press mud, a solid fibrous residue generated during sugar cane juice clarification and filtration, represents around $2.8-4.5 \%$ $(w / w)$ of the milled sugar cane.

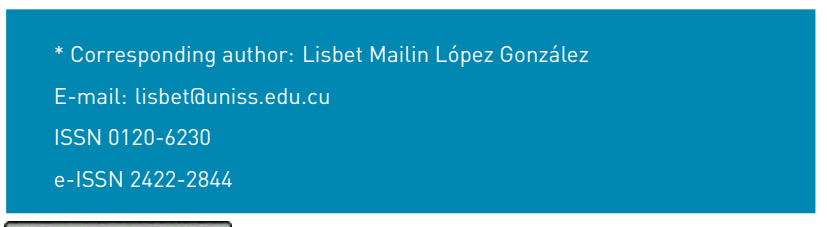

Typically, press mud is used as fertilizer/soil improver; being directly (or after composting) applied on the soils in association or not with other minerals.

The anaerobic mono-digestion of press mud for biogas production has been previously reported in full and laboratory scale studies [1, 2]. The inclusion of a pre-treatment stage for press mud was considered as a potential alternative in terms of methane yield by [1]. However, an energetic and economic analysis of press mud pre-treatments is still needed to assess feasibility for future implementations. 
To our knowledge, only few studies have been focused on the effect of substrate pre-treatments on profitability indicators and net energy production [3-6]. These authors investigated the impact of thermobarical treatment on solid cattle waste; steam explosion pre-treatment on wheat straw and cow manure; and thermo-alkaline (TA) pre-treatment on sugar cane straw.

Other studies have been addressed to assess the environmental sustainability of the biogas production process in different scenarios from a life cycle perspective $[7,8]$ and based on $G H G$ emissions $[5,9,10]$. Four alternatives for using by-products and wastes from the sugar cane industry were compared [7]. In the impact category "resource", the best alternative considered biogas production from press mud, sugar industry wastewater, and vinasse. Despite of that, environmental profiles when press mud is pretreated for $A D$ and co-digested with vinasse were not included.

Therefore, this paper assesses the energetic, economic and environmental feasibility for the $A D$ of press mud previously pretreated with LHW or TA methods.

\section{Materials and methods}

The aim of this work was to assess press mud pre-treatment alternatives regarding the energetic (energetic balance), economic (Net Present Value (NPV), Internal Rate of Return (IRR) and Payback Period (PBP) and environmental lendpoint impact categories "ecosystem quality", "human health" and "natural resources" using Life Cycle Analysis, (LCA)). Main energetic, economic and environmental considerations are described in detail below.

\subsection{Case study}

A typical Cuban sugar mill was selected as a Case Study. The sugar mill has a potential capacity to process 4,600 $\mathrm{t} \mathrm{d}^{-1}$ of sugar cane and operates 130 days per year. The biogas produced can be used to feed an internal combustion engine to produce electricity and heat. It was assumed that the electricity will be sold to the national electric grid and the heat recovered from the exhaust gases will be used as energy source to supply the thermal demand for press mud pre-treatments.

\subsection{Alternatives description}

The alternatives (A1-A3) were proposed according to the optimal operating conditions reported for press mud pre-treatment $[1,2]$. A1: $A D$ of press mud without pre-treatment. $A 2$ : $A D$ of pretreated press mud using $\mathrm{LHW}$ pre-treatment $\left(150^{\circ} \mathrm{C}, 20\right.$ minutes). $\mathrm{A} 3$ : $A D$ of pretreated press mud using TA pre-treatment $(10 \mathrm{~g} \mathrm{Ca} \mathrm{OH})_{2} 100 \mathrm{~g}^{-1}$ Total Solids (TS), 1 hour, $100{ }^{\circ} \mathrm{C}$ ). The environmental mitigation potential of the biogas production was assessed with respect to a reference scenario (current conditions) referred as the use of press mud for sugar cane fertilization after composting $(\mathrm{AO})$.

The main considerations for energetic, economic and environmental assessment are shown in Table 1.

\subsection{Energetic considerations}

The produced biogas will be burned in a combined heat and power system (CHP), generating electrical energy (EE) for the national electric grid and thermal energy (TE) to produce steam at low pressure from the exhaust gases. Scenarios considering biogas injection into the gas grid, bottling or direct use in steam boilers, were beyond the scope of this work, being relevant for future analysis as these are important application strategies for the global energetic situation.

As basis for calculations, it was considered that the biogas plant works 300 days a year, with a daily feeding of $70 \mathrm{t} \mathrm{d}^{-1}$ of press mud $3.5 \%$ of press mud contained in the milled cane of sugar.

The energy balance was carried out to assess energy demand for pre-treatments versus energy recovered from biogas increments.

The thermal energy consumed during pre-treatment

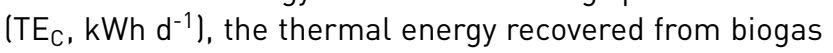
$\left(T E_{R}, k W h d^{-1}\right)$, the thermal energy required based on the efficiency of the hydrolysis reactor $\left(T E_{R Q}, k W h d^{-1}\right)$, and the electrical energy generated (EE, $\mathrm{kWh} \mathrm{d}^{-1}$ ), were calculated according the equations from Equation 1 to Equation 4.

$$
\begin{gathered}
T E_{c}\left(\frac{k W h}{d}\right)=m \cdot c_{p} \cdot \Delta \mathrm{T} \cdot \mathrm{t}_{\mathrm{p}} / 3600 \\
T E_{R}\left(\frac{k W h}{d}\right)=y_{B} \cdot V_{c} \cdot \eta_{t} \\
T E_{R Q}\left(\frac{k W h}{d}\right)=T E_{R} / \eta_{H} \\
E E\left(\frac{k W h}{d}\right)=y_{B} \cdot V_{c} \cdot \eta_{e}
\end{gathered}
$$

Where $\mathbf{m}$ is the mass of the press mud and water mixture to be fed $\left(\mathrm{kg} \mathrm{h}^{-1}\right), \mathbf{c}_{\mathbf{p}}$ is the heat capacity of the mixture (it is considered equal to the water, $4.18 \mathrm{~kJ} \mathrm{~kg}^{-1} \mathrm{~K}^{-1}$ J, $\Delta \mathbf{T}$ is the increment of the temperature $(\mathrm{K}), \mathbf{t p}$ is the pre-treatment time per $\operatorname{day}(\mathrm{h}), \mathbf{y}_{\mathbf{B}}$ is the biogas production $\left(\mathrm{m}^{3} \mathrm{~d}^{-1}\right), \mathbf{V}_{\mathbf{c}}$ is the biogas calorific value $\left(\mathrm{kWh} \mathrm{m}^{-3}\right), \boldsymbol{\eta}_{\mathbf{t}}$ the thermal 
Table 1 Main considerations for energetic, economic and environmental assessment

\begin{tabular}{|c|c|c|c|}
\hline General data & & & Reference \\
\hline Density of methane at $0^{\circ} \mathrm{C}$ & $\mathrm{kg} \mathrm{m}^{-3}$ & 0.72 & \\
\hline Density of biogas at $0^{\circ} \mathrm{C}$ & $\mathrm{kg} \mathrm{m}^{-3}$ & 1.28 & [11] \\
\hline Hours of operation per year & $\mathrm{h}$ & 300 & \\
\hline \multicolumn{4}{|l|}{ Energetic considerations } \\
\hline Lower heating value for methane & $M J k g^{-1}$ & 50.01 & \\
\hline Specific heat capacity of water $\left(c_{p}\right)$ & $\mathrm{kJ} \mathrm{kg}^{-1} \mathrm{~K}^{-1}$ & 4.18 & [12] \\
\hline Biogas calorific value $\left(V_{C}\right)$ & $\mathrm{kWh} \mathrm{m}^{-3}$ & 6.5 & \\
\hline Hydrolysis reactor efficiency $(\eta \mathrm{H})$ & $\%$ & 80 & [6] \\
\hline \multicolumn{4}{|c|}{ Economical and environmental considerations } \\
\hline Equipment investment-biogas plant & $\begin{array}{l}\text { USD } \\
\mathrm{m}^{3} \text { reactor }\end{array}$ & $\begin{array}{l}911556.00 \\
6231\end{array}$ & [13] \\
\hline Equipment investment-Hydrolysis reactor & $\begin{array}{l}\text { USD } \\
\mathrm{m}^{3} \text { reactor }\end{array}$ & $\begin{array}{l}250000.00 \\
3 \mathrm{~m}^{3}\end{array}$ & [5] \\
\hline Index maintenance cost & $\% \mathrm{CFI}$ & 2 & [14] \\
\hline Index electricity cost & $\begin{array}{l}\% \mathrm{~m}^{3} \\
\text { biogás }\end{array}$ & 5 & [12] \\
\hline Price purchase $\mathrm{Ca}(\mathrm{OH})_{2}$ & USD/t & 250 & [15] \\
\hline Price purchase press mud & USD/t & 2 & [16] \\
\hline Price purchase electricity & USD/kWh & 0.09 & [16] \\
\hline Price purchase water & $\mathrm{USD} / \mathrm{m}^{3}$ & 0.25 & [16] \\
\hline Price purchase fuel oil & USD/t & 349.76 & [17] \\
\hline Price sale fertirrigation water & USD/m³ & 1.20 & [18] \\
\hline Price sale avoided carbon & USD/t & 25.07 & [19] \\
\hline $1 \mathrm{t} \mathrm{CH}_{4}$ & $\mathrm{tCO}_{2} \mathrm{eq}$ & 34 & [20] \\
\hline
\end{tabular}

efficiency of the CHP (\%), $\boldsymbol{\eta}_{\mathbf{e}}$ the electric efficiency of the $\mathrm{CHP}(\%)$ and $\eta_{\mathrm{H}}$ the hydrolysis reactor efficiency. The values of $\boldsymbol{\eta}_{\mathbf{t}}$ and $\boldsymbol{\eta}_{\mathbf{e}}$ are selected according to the installed engine power. An index of $3.1 \mathrm{kWh} \mathrm{tTS}^{-1}$ was used to calculate the electrical energy consumption $\left(E E_{C}\right)$ during pre-treatments [5].

\subsection{Economic considerations}

For the economic assessment, the total investment cost, the total production cost and the cash flow for each alternative were estimated. To calculate the fixed-capital and the total capital investment was used the methodology recommended by [14]. The six-tenths-factor rule updating their values to the current prices with the Chemical Engineering Plant Cost Index was used to calculate the purchased equipment (E) for LHW pre-treatment and equipment for biogas plant (without CHP system). An offer of the German company "Biogas Nord" with a total equipment cost of 911556.00 USD (reactor volume of $6,231 \mathrm{~m}^{3}$ ) for the equipment purchased for biogas plant (without CHP system) was used as base cost [13], while the hydrolysis reactor in the LHW pre-treatment was calculated using a value of 250000.00 USD (reactor volume of $3 \mathrm{~m}^{3}$ ) reported by [5]. For TA pre-treatment, the volume of the lime preparation tank and the hydrolysis reactor were calculated according to the feeding daily and pre-treatment time. The equipment investment cost was estimated by [21]. To estimate the cost of the electricity generator, cost indexes based on the requirement of the electrical power plant were used [22].

Biogas purification unit is included in the base cost for the equipment for biogas plants. The method of removing $\mathrm{H}_{2} \mathrm{~S}$ is the in-situ desulphurization in the biogas digester itself by dosing air to the gas phase. Oxygen is consumed by bacteria of the species Thiobacillus during the oxidation of $\mathrm{H}_{2} \mathrm{~S}$ to elemental sulphur which precipitates on surfaces or is absorbed by the slurry [23]. Water content in the biogas is removed with a water tramp. To determine fixed and variable costs, was used the methodology recommended by [14]. Linear depreciation was considered over 10 years for installed technical equipment. It was considered an interest rate of $10 \%$ for total investment cost, an inflation rate of $8 \%$, and a tax rate of $30 \%$. As revenues for the biogas plant, the sale of electricity, the economic savings due to fuel oil substitution at distillery (in sugar cane non-harvest periods), the sale of avoided $\mathrm{CO}_{2}$ emissions, and the sales of organic fertilizers and ferti-irrigation water. 


\subsection{Enviromental considerations}

For the environmental assessment of the alternatives, the mitigation potential of the biogas production in comparison with the reference scenario was estimated. It was assumed for this scenario (reference scenario $\mathrm{A} 0$ ) the production of compost from press mud and its contribution as organic carbon to the soil. The daily treatment of 70 ton of press mud was considered as the functional unit for Life Cycle Analysis (LCA), producing between 12.2-19.7 MWh of electricity, 17.3-27.9 MWh of heat and 2.3-8.4 ton of organic carbon.

The system boundaries and scenarios are shown in Figure 1. It shows the gaseous emissions from composting, as well as the combustion gasses from the energy generation emitted to the ecosphere. Oxygen content in the air and land used are the resources taken from the ecosphere whereas energy, press mud, calcium oxide and tap water are the resources taken from the technosphere. The products are electricity, heat and organic carbon. Traditional supply chains (TSC) are the common suppliers of products (e.g. electricity produced from fuel oil in centralized power plants); they take resources from the technosphere to produce the required products for the market.

In order to make a fair comparison between the alternatives an equal basket of benefits was constructed, which implies that TSC always need to complete the market demand and fulfil an equal basket of benefits. For example, when press mud is pre-treated by LHW (A2), 2.1 MWh of electricity are produced, as this is the maximum energy production between the alternatives $A 0, A 1, A 2$ and $A 3$, the difference of each alternative respect to $A 2$ must be supplied by the TSC of electricity.

It was assumed that TSC provide the electricity according to the Cuban electricity mix (fuel oil that is used in centralized and decentralized thermal power plants $(81.66 \%)$, combined cycles with gas turbine using liquefied petroleum gas (13.04\%), cogeneration systems using bagasse $(4.63 \%)$, and other technologies using renewable resources $(0.67 \%)$, the heat as steam from fuel oil, the organic carbon was assumed to be extracted from the soil as "Carbon, in organic matter, in soil" and the ferti-irrigation water as river water [8].

The main assumptions for this study were as follows:

- All calculations are based on 1 day of operation.

- The electricity and heat produced from biogas, as well as organic fertilizer (Corg) were variable among the alternatives. The amount of $N, P$ and $K$ was considered constant.
- Organic carbon was taken from the Ecoinvent Database 2.2 as "Carbon, in organic matter, in soil" and it was assumed to be consumed in the all the alternatives, except the one with the highest organic carbon production which does not consume/extract organic carbon from the soil.

- A $2 \%$ of biogas losses were assumed during the production process, power generation and storage of the digested effluent [10].

- For press mud composting process, the emissions reported from composting were considered [24].

$$
\begin{aligned}
& \text { Emission } \mathrm{CH}_{4} \text { from composting } \mathrm{kg} \mathrm{kg}^{-1} \text { waste } \\
& 0.004 \\
& \text { Emission } \mathrm{N}_{2} \mathrm{O} \text { from composting } \mathrm{kg} \mathrm{kg}^{-1} \text { waste } \\
& 0.003
\end{aligned}
$$

To account for emissions and resources the RECIPE methodology with endpoint indicators and the hierarchic perspective was used [25]. Therefore, the endpoint impact categories "ecosystem quality", "human health" and "natural resources" were estimated. The environmental impacts were quantified in "Points" for the endpoint impact categories and for the total score (sum of the endpoint scores). The open source software for the sustainability assessment, OpenLCA version 1.3.1 was used to calculate the environmental impacts.

\section{Results and discussion}

\subsection{Energetic assessment}

Table 2 shows a summary of the energy balances for the alternatives considering the pre-treatment of press mud (A2 and A3) and for press mud without pre-treatment (A1).

EE: Electrical energy produced. $\mathrm{ET}_{\mathrm{R}}$ : Thermal energy recovered, $E_{\mathrm{C}}$ : Electrical energy consumed, $\mathrm{ET}_{\mathrm{C}}$ : Thermal energy consumed, $E T_{Q}$ : Thermal energy required, $E T_{N}$ : Net thermal energy, $\mathrm{EE}_{\mathrm{N}}$ : Net electrical energy, $\eta \mathrm{e}$ : Electrical efficiency and $\eta$ t: Thermal efficiency for engine Jenbacher [26].

The $T E_{R}$ for pretreated press mud by $T A$ (A3) and LHW (A2) was $10 \%$ and $61 \%$ higher, respectively, with respect to untreated press mud, while for the EE was $27 \%$ and $61 \%$ higher, respectively. According to the energy balance, more energy than required was recovered $\left(T E_{R}\right)$ for TA and LHW pre-treatments, being concluded that both pre-treatments are self-sufficient.

The electric and thermal net energy for the studied

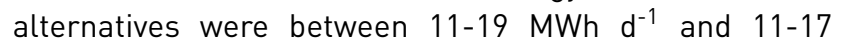
$M W h d^{-1}$, respectively. Specifically, the alternative that 


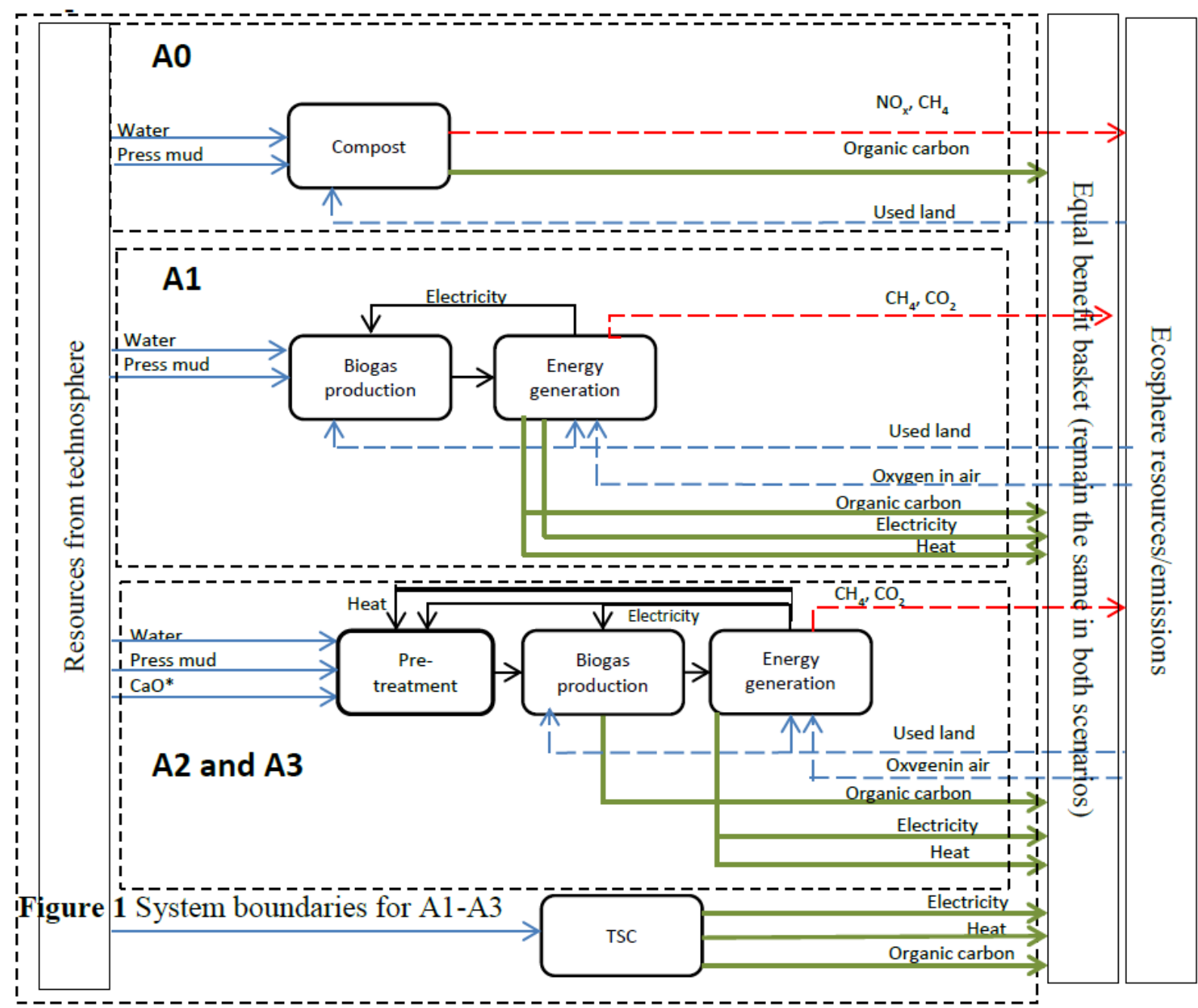

Inputs from technosphere $\longrightarrow$ Emissions from ecosphere $---\rightarrow$ Products Internal flows $\longrightarrow$ Resources from ecosphere $--->$

Background: Production by the traditional supply chain (TSC)

${ }^{*} \mathrm{CaO}$ only is consumed for $\mathrm{A} 3$.

Figure 1 System boundaries for A1-A3

Table 2 Energy balance for the alternatives considered

\begin{tabular}{|c|c|c|c|c|c|c|c|c|c|}
\hline & \multicolumn{4}{|c|}{ Generation } & \multicolumn{3}{|c|}{ Consumption } & \multicolumn{2}{|c|}{ Benefits } \\
\hline Alternatives & $\begin{array}{l}\text { Biogas } \\
\left(\mathrm{m}^{3} \mathrm{~d}^{-1}\right)\end{array}$ & $\begin{array}{l}\text { Electric } \\
\text { Power } \\
(\mathrm{kW})\end{array}$ & $\begin{array}{l}\text { EE } \\
\text { (MWh } \\
\left.\mathrm{d}^{-1}\right) \\
\end{array}$ & $\begin{array}{l}E T_{R} \\
(M W h \\
\left.d^{-1}\right) \\
\end{array}$ & $\begin{array}{l}E_{C} \\
(M W h \\
\left.d^{-1}\right) \\
\end{array}$ & $\begin{array}{l}\mathrm{ET}_{\mathrm{C}} \\
(\mathrm{MWh} \\
\left.\mathrm{d}^{-1}\right) \\
\end{array}$ & $\begin{array}{l}E T_{R Q} \\
(M W h \\
\left.d_{-1}\right) \\
\end{array}$ & $\begin{array}{l}E T_{N} \\
(M W h \\
\left.d^{-1}\right) \\
\end{array}$ & $\begin{array}{l}\mathrm{EE}_{\mathrm{N}} \\
(\mathrm{MWh} \\
\left.\mathrm{d}^{-1}\right) \\
\end{array}$ \\
\hline A1 & 5484 & $\begin{array}{l}848 \\
(\eta \mathrm{e}=38.3 \\
\eta \mathrm{t}=47.6)\end{array}$ & 12.3 & 17.0 & 12 & & & 17.0 & 11.1 \\
\hline A2 & 8856 & $\begin{array}{l}1059 \\
(\eta \mathrm{e}=40.8 \\
\eta \mathrm{t}=41.7)\end{array}$ & 21.1 & 24.0 & 2.2 & 9.6 & 12.1 & 11.9 & 18.9 \\
\hline A3 & 6668 & $\begin{array}{l}848 \\
(\eta \mathrm{e}=38.3 \\
\eta \mathrm{t}=47.6)\end{array}$ & 14.9 & 20.6 & 1.6 & 7.5 & 9.4 & 11.3 & 13.4 \\
\hline
\end{tabular}


considers press mud without pretreatment $(\mathrm{A} 1)$ rendered the highest thermal energy (17 $\left.\mathrm{MWh} \mathrm{d}^{-1}\right)$, while the one considering pretreatment by LHW (A2) rendered the highest electric (19 $\mathrm{MWh} \mathrm{d}^{-1}$ ) energy.

\subsection{Economic assessment}

Alternative $A 2$ had the highest investment cost with 5.0 million USD, taking into account the investment cost of LHW pre-treatment of press mud and the fact that A2 has the highest installed capacity $(1,059 \mathrm{~kW})$. An index calculated of $279 \mathrm{USD} / \mathrm{m}^{3}$ reactor calculated for the biogas plant fed with press mud untreated is lower to the one reported for sugarcane straw of $354 \mathrm{EUR} / \mathrm{m}^{3}$ lequivalent to $400 \mathrm{USD} / \mathrm{m}^{3}$ reactor) [3]. For the alternatives with pre-treatment $A 2$ and $A 3$, the index was 948 and 702 $\mathrm{USD} / \mathrm{m}^{3}$.

The $74 \%$ of the revenues distributed between the sales of electricity and biofertilizer. The highest incomes from electricity sale were for A2 and A3 1828 and 624 MUSD/year, respectivelyl while for $A 1$ the incomes by sales of biofertilizer were similar than that of electricity (Table 3).

Table 3 Material and labor costs (MUSD/year) and revenues for the assessed scenarios

\begin{tabular}{|c|c|c|c|}
\hline & A1 & A2 & A3 \\
\hline \multicolumn{4}{|l|}{ Incomes } \\
\hline Electricity sales & 489.09 & 829.00 & 624.19 \\
\hline Petroleum savings & 89.17 & 160.22 & 118.64 \\
\hline $\begin{array}{l}\text { Carbon credit } \\
\text { comercialization }\end{array}$ & 183.60 & 175.02 & 180.60 \\
\hline Ferti-irrigation water & 61.55 & 61.55 & 61.55 \\
\hline Fertilizer sales & 465.22 & 465.22 & 465.22 \\
\hline \multicolumn{4}{|l|}{ Material and labor cost } \\
\hline Raw material & 41.86 & 41.86 & 41.86 \\
\hline Water & 5.93 & 5.93 & 5.93 \\
\hline Calcium hydroxide & 0.00 & 0.00 & 144.94 \\
\hline Electricity & 34.94 & 61.67 & 42.01 \\
\hline Maintenance & 8.71 & 10.03 & 7.43 \\
\hline Labor & 21.60 & 21.60 & 21.60 \\
\hline
\end{tabular}

For all the alternatives water for dilution was only consumed in non-harvest season. During the harvest season $2,760 \mathrm{~m}^{3} \mathrm{~d}^{-1}$ of wastewater from cane sugar production process are generated. This wastewater can be used for reducing the press mud TS content, regarding to keep $<8 \%$ TS $\left(140 \mathrm{~m}^{3} \mathrm{~d}^{-1}\right.$ is needed) inside the CSTR.

The electricity cost represents the $53 \%$ and $66 \%$ of the direct production costs for $\mathrm{A} 1$ and $\mathrm{A} 2$, respectively, followed by raw material cost with $25 \%$ and $18 \%$, respectively. For A3 the calcium hydroxide (consumption of $2 \mathrm{t} \mathrm{d}^{-1}$ ) and the electricity costs had the same contribution to the direct production costs.

The feasibility of the investment was also assessed. All alternatives were economically feasible (IRR> 10\%), but the alternative considering the press mud pretreated by LHW was the most profitable with a NPV of 3168731.49 USD, 5.3 years for PBP and an IRR of $22 \%$.

An analysis of the economic feasibility of the use of the biogas, obtained from the vinasse anaerobic digestion, as fuel, was carried out by [27]. Different scenarios were evaluated, like: electric power generation through Reciprocating Combustion Engines (RCE), gas turbines and microturbines (MT), and the use of the biogas, as fuel, in spray drying of thermal sensible bioproducts (yeasts) to be commercialized. The payback was between 1.8-7.8 years, with 3.6 years for the case of the electricity generation using RCE, a lower value than that obtained in this work.

The feasibility of thermobarical pre-treatment for full-scale application was assessed by [5]. The energetic analysis showed a higher recovery of thermal energy from the pre-treated feedstock than required for pre-treatment. The pre-treatment of solid cattle wastes revealed short payback periods. The total investment costs using steam explosion pre-treatment was increased by $13 \%$, but reducing the manufacturing cost by $36 \%$ the economy of the biogas plant was improved [4].

\subsection{Enviromental assessment}

From the LCA, an improvement was obtained in the environmental profile with respect to the baseline conditions, which was evidenced in the reduction between $62 \%(\mathrm{~A} 3)$ and $97 \%(\mathrm{~A} 2)$ of the total score with respect to $A 0$ (Figure 2).

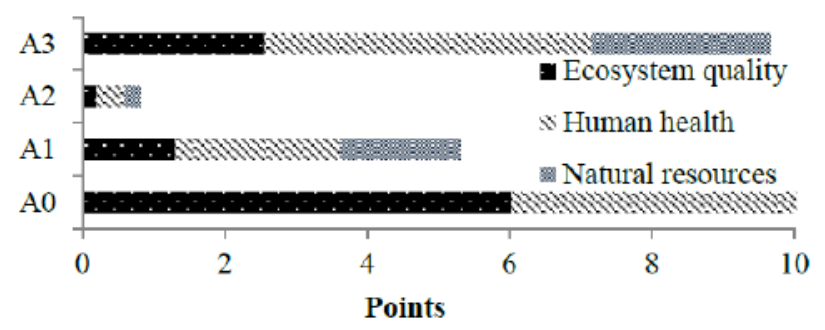

Figure 2 Environmental impacts for the alternatives [A0-A3]

The best results were obtained when press mud was pretreated by LHW to feed the CSTR reactor. This was explained from the highest methane production in this alternative, the production of the highest amount of electricity and heat and consequently the lower energy demanded from TSC to achieve the equal basket of 


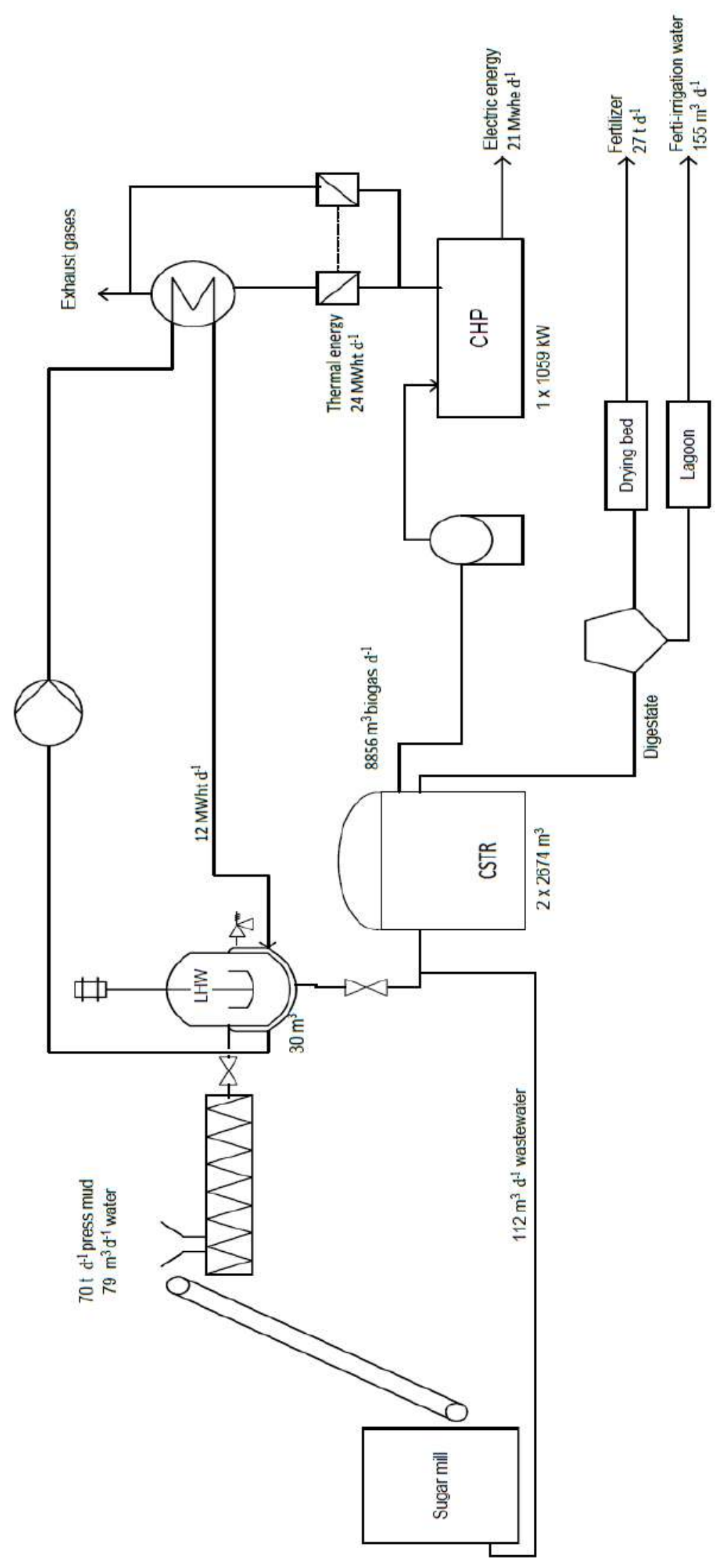

Figure 3 Diagram of flow for the alternative A2 
benefits. According to the results obtained from the energetic, economic and environmental analysis of press mud pre-treatment alternatives for $A D$, the digestion of press mud pretreated by LHW (A2) was the most viable (Figure 3).

The highest contribution to the endpoint impact categories was "Human Health", which represents $43-49 \%$ of the total punctuation. This result was mainly attributed to the intermediate impact category "Climate change" (54-62\%) and is due to the burning of fossil fuel in the refinery to supply the required electricity. The "Human toxicity" (32-36\%) and the "Formation of particulate material" had a lower contribution (6-12\%).

The LCA results agree with environmental benefits reported for the anaerobic digestion in the Cuban sugar factories [7, 8]. However, direct comparison with the results in the current study is not possible as different assumptions, functional units, types of systems and life cycle impacts assessment methodologies were used.

Four alternatives for using by-products and wastes from the sugar mill and ethanol distilleries were compared, from a life cycle perspective, in a study carried out by [7]. The highest benefits were obtained for the alternatives considering biogas production from press mud, sugar mill wastewater, and vinasse. In another research a comparative assessment of anaerobic digestion power plants as alternative to lagoons for vinasse treatment was reported [8]. In this study, the environmental profile was improved with respect to the lagooning of Cuban vinasse, reducing up to $77 \%$ the total score. The endpoint impact category "ecosystem quality" contributed to more than $37 \%$ of the total score, where the midpoint impact category "agricultural land occupation" had the largest contribution $(60 \%)$. This result was mainly attributed to differences in the required surface area for lagooning when $70 \%$ of the organic matter is removed at the biogas production.

\section{Conclusions}

The present study demonstrated the possibility to make use of the press mud obtained in a sugar mill to generate electricity, keeping its use as bio fertilizer, in a profitable way. The incorporation of a pretreatment stage, either by TA or LHW, increased the required investment and the operational expenditures of the $A D$ process, but the profitability of methane production was improved in comparison with the untreated press mud. LHW and TA pre-treatments shown are self-sufficient in terms of thermal requirements since they can recover heat from the biogas engine. From the environmental point of view the alternative $\mathrm{A} 3$ (adding $\mathrm{Ca}(\mathrm{OH})_{2}$ at $100^{\circ} \mathrm{C}$ ) obtained a higher environmental impact, than untreated press mud and LHW pretreatment.

According to the results obtained from the energetic, economic and environmental analysis of press mud pre-treatment alternatives for $A D$, the digestion of press mud pretreated by LHW (A2) was the most viable. Such results provide important inputs for designing the $A D$ process using press mud as substrate encouraging the efficient utilization of one of the major residual biomass from the sugarcane industry for a sustainable biofuel production in a biorefinery concept.

\section{Acknowledgements}

This research was supported by the VLIR-UOS project entitled "Biogas production from waste from local food, wood and sugarcane industries for increasing self-sufficiency of energy in Sancti Spiritus, Cuba".

\section{References}

[1] L. M. López and et al., "Effect of liquid hot water pre-treatment on sugarcane press mud methane yield," Bioresour. Technol., vol. 169. pp. 284-290, Oct. 2014.

[2] L. M. López and et al., "Thermo-chemical pre-treatment to solubilize and improve anaerobic biodegradability of press mud," Bioresour. Technol., vol. 131, pp. 250-257, Mar. 2013.

[3] L. Janke and et al., "Improving anaerobic digestion of sugarcane straw for methane production: Combined benefits of mechanical and sodium hydroxide pretreatment for process designing," Energy Convers. Manag., vol. 141, pp. 378-389, Jun. 2017.

[4] M. Shafiei, M. M. Kabir, H. Zilouei, I. S. Horváth, and K. Karimi, "Techno-economical study of biogas production improved by steam explosion pretreatment," Bioresour. Technol., vol. 148, pp. 53-60, Nov. 2013

[5] J. Budde, A. Prochnow, M. Plochl, T. Suárez, and M. Heiermann, "Energy balance, greenhouse gas emissions, and profitability of thermobarical pretreatment of cattle waste in anaerobic digestion," Waste Manag., vol. 49, pp. 390-410, Mar. 2016.

[6] R. Cano, A. Nielfa, and M. Fdz, "Thermal hydrolysis integration in the anaerobic digestion process of different solid wastes: energy and economic feasibility study," Bioresour. Technol., vol. 168, pp. 14-22, Sep. 2014.

[7] A. M. Contreras, E. Rosa, M. Perez, H. V. Langenhove, and J. Dewulf, "Comparative Life Cycle Assessment of four alternatives for using by-products of cane sugar production," J. Clean. Prod., vol. 17, no. 8 , pp. 772-779, May 2009.

[8] E. L. Barrera and et al., "A comparative assessment of anaerobic digestion power plants as alternative to lagoons for vinasse treatment: life cycle assessment and exergy analysis," J. Clean. Prod., vol. 113, pp. 459-471, Feb. 2016.

[9] B. S. Moraes, S. O. Petersen, M. Zaiat, S. G. Sommer, and J. M. Triolo, "Reduction in greenhouse gas emissions from vinasse through anaerobic digestion," Appl. Energ., vol. 189, pp. 21-30, Mar. 2017.

[10] A. Meyer and et al., "Impact of uncertainties on greenhouse gas mitigation potential of biogas production from agricultural resources," Renew. Energ., vol. 37, no. 1, pp. 277-284, Jan. 2012.

[11] Fermentation of organic materials characterisation of the substrate, sampling, collection of material data, fermentation tests, VDI 4630 , 2016.

[12] Guía sobre el Biogás. Desde la producción hasta el uso, Fachagentur Nachwachsende Rohstoffe e. V. (FNR), Eschborn, Germany, 2013. 
[13] Estudio de pre-factibilidad de plantas de biogás. Empresa Azucarera Melanio Hernández. Nro 6050684TG01000, IPROYAZ, Sancti Spiritus, CU, 2007.

[14] M. S. Peters and K. D. Timmerhaus, Plant design and economics for Chemical Engineers, 4th ed. Singapore: McGraw-Hill, 1991.

[15] Quiminet. Accessed Mar. 15, 2019. [Online]. Available: https: //bit.ly/2UKQIC2

[16] Price charge of the products. Accounting and finances department, Unidad Empresarial de Base Central Azucarero Melanio Hernández, Sancti Spiritus, CU, 2019.

[17] (2013) Boletín de información económica banco central de cuba (bcc). BCC. Accessed Mar. 28, 2019. [Online]. Available: https: //bit.ly/2Z4n3NM

[18] Manual de biogás, Organización de las Naciones Unidas para la Agricultura y la Alimentación, Santiago de Chile, Chile, 2011.

[19] (2019) Sistema europeo de negociación de $\mathrm{CO}_{2}$. Sende $\mathrm{CO}_{2}$. Accessed Mar. 17, 2019. [Online]. Available: https://bit.ly/2SGq8Dy

[20] T. F. Stocker and et al. (2013) The physical science basis. in: Contribution of working group $i$ to the fifth assessment report of the intergovernmental panel on climate change. IPCC. New York, USA. [Online]. Available: https://bit.ly/2PBlmDg
[21] (2014) Matches' process equipment cost estimates. Matches. Accessed Feb. 01, 2019. [Online]. Available: http://www.matche. $\mathrm{com} /$

[22] (2015) Environmental protection agency combined heat and power partnership. catalog of technologies: Section 2. technology characterization - reciprocating internal combustion engines. EPA. Accessed Mar. 10, 2018. [Online]. Available: https://www.epa.gov/

[23] M. Miltner, A. Makaruk, and M. Harasek, "Review on available biogas upgrading technologies and innovations towards advanced solutions," J. Clean. Prod., vol. 161, pp. 1329-1337, Sep. 2017.

[24] Directrices del IPCC de 2006 para los Inventarios Nacionales de Gases de Efecto Invernadero: Desechos- Tratamiento y eliminación de aguas residuales, IPCC, 2006.

[25] M. J. Goedkoop and et al., “Recipe 2008: A life cycle impact assessment method which comprises harmonised category indicators at the midpoint and the endpoint level," 012008.

[26] (2015) Jenbacher type 3. GE Power and Water. Accessed Feb. 01, 2019. [Online]. Available: https://bit.ly/2LIPjZo

[27] K. R. Salomon, S. Lora, M. H. Rocha, and O. Almazán, “Cost calculations for biogas from vinasse biodigestion and its energy utilization," Sugar Industry, vol. 136, no. 4, pp. 217-223, Jan. 2011. 